\title{
Racism amongst white Afrikaner adolescents: The challenge of $I$-Thou (Buber) relations
}

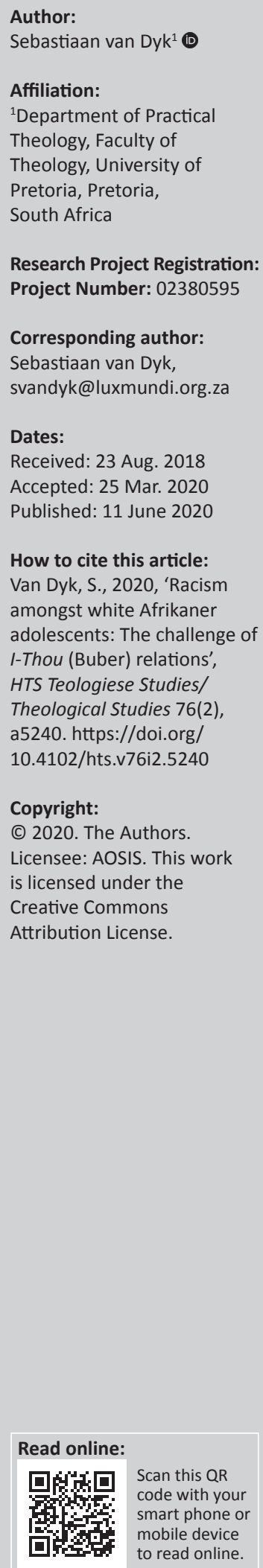

This article was derived from my doctoral thesis, 'Post-apartheid racism among Afrikaans speaking urban adolescents: A narrative-pastoral reflection'. The impetus for this study was the seemingly increasing occurrences of racism amongst post-apartheid Afrikaans-speaking urban adolescents in South Africa by taking a narrative practical theological perspective on the matter to help build meaningful cross-cultural dialogue. This study explored the level of dialogue of the participants using a postfoundational paradigm. Two questions guided the investigation: (1) How deeply embedded are objectifying of cross-cultural relationships? (2) How can we instigate honest dialogue aiding us in being more aware of our biases to embrace diversity and going forward as a unity in diversity? This study was conducted in 2016 amongst white Afrikaans-speaking urban adolescents living in Pretoria-East, South Africa. I had four group conversations (A, B, C and D) with my co-researchers (research participants), with six to eight adolescents per group. I made use of certain empirical research methods, such as narrative interviewing and group discussions. From an epistemological perspective, a postfoundational, social constructionist perspective, including an autoethnographical approach, was followed. The research indicated that Afrikaner adolescents could live life unquestioned from a position of power and objectivity that was culturally inherited. It was found that by objectifying relationships (I-It), diverse engagement becomes almost impossible. Consequently, this article advocates for a dialogical (I-Thou) approach towards building relationships in a context where people feel vulnerable and shameful, have fears, but also gain trust to contribute to meaningful dialogue with 'others'.

Keywords: Racism; Afrikaner; Buber; Adolescents; Narrative.

\section{Introduction and background}

I was born and bred in South Africa. My earliest memories are being a carefree youngster on a farm. My best buddy was Kenith, our domestic worker's son. At that point in time, I did not realise that, although we lived shared lives, domestic workers were treated as inferiors in many ways. Later we moved to a town. It was the turbulent period of unrest in townships and the transition from apartheid to democracy. The greater part of my family was fearful racists. Instead of appreciating and celebrating South African diversity (Giliomee 2003; Giliomee \& Mbenga 2007), I am ashamed to admit that I 'inherited' their racism story - a story that starts with white supremacy; a story I was born into with a certain history, a story that shaped me to think in no other way, at least for a big part of my life; a story that is so part of me that it is almost too difficult to shake its grip from me; a story that could be dangerous even within the best of intentions to help others. My exposure to practical theology taught me to listen (Müller 2013:3). Through 'listening' I discovered that voices of those different to me were not threatening but beautiful voices enriching me. Slowly but surely I was freed from the yoke of racism.

After my theological studies, I was called to the Dutch Reformed Church Lux Mundi as a youth minister. Here I had the opportunity of doing and living practical theology (Heitink 1999:106; see also Heitink 1999:9; Meylahn 2014, 2015) amongst adolescents in the Afrikaans-speaking urban community. I had a 12-year relationship with this specific congregation and with most of the co-researchers described in this article. I've known them since their early primary school years. As a racist in recovery, I was often saddened by the racism I had encountered in those I ministered to. This left me with the following unanswered questions: 'How can one be a God loving Christian and at the same time be a racist? How is this even possible?'

Note: This article is published in the section Practical Theology of the Society for Practical Theology in South Africa. 
Enrolling for a doctoral thesis on this sensitive topic of racism, the opportunity arose to deconstruct racism in my ministered constituency. The result of this endeavour was my thesis, 'Post-apartheid racism among Afrikaans speaking urban adolescents: A narrative-pastoral reflection'.

\section{Methodology}

This study was carried out within the philosophical guidelines of narrative therapy (Besley 2002; Freedman \& Combs 1996; Monk et al. 1997) and a postfoundational practical theology (Müller 2006, 2009a, 2009b, 2011, 2013). This study was conducted in 2016 amongst white Afrikaansspeaking urban adolescents (male and female, aged 16-19) living in Pretoria-East, South Africa. I had four group conversations (Group A, B, C and D) with my co-researchers (research participants) comprising six to eight adolescents in each group, with a combined total of 26 co-researchers. The identities of the co-researchers are not revealed, however, three unique identifiers are used to validate their statements. For example, participant B2-16-F is a 16-year-old female and participant C2-17-M is a 17-year-old male. I made use of certain empirical research methods, such as narrative interviewing and group discussions.

From an epistemological perspective, a postfoundational, social constructionist perspective, including an autoethnographical approach, was followed. This supports the research design which was based on the principles of narrative practical theology.

The research indicated that Afrikaner adolescents could live life unquestioned from a position of power and objectivity that was culturally inherited. It was found that by objectifying relationships (I-It) diverse engagement becomes almost impossible.

Consequently, this article advocates for a dialogical (I-Thou) approach towards building relationships in a context where people feel vulnerable and shameful, have fears, but also gain trust to contribute to meaningful dialogue with 'others'.

How deep are racism stereotypes (traditions or interpretation) embedded in the lives of these adolescents? How possible is honest deconstructing of dominant discourses in helping us realise or be aware of our biases so that we could embrace diversity in our so-called 'rainbow nation' going forward as a unity in diversity? In this article, Buber's (1958) I and Thou philosophy of personal dialogue is explored as a way forward. According to Buber (1958), human existence is defined by how we engage in dialogue with God, the world and with each other. According to his theory, I-Thou is a relation of subject-to-subject, of mutuality and reciprocity, whilst I-It is a relation of subject-to-object, of separateness and detachment.

The importance of dialogue and listening is well documented by Müller (2013) as is racism in general by Blum (2002:4-5) and Yang (2000:144) as well as racism in South Africa after two decades from various perspectives by Baloyi (2018:2-3), Mashau (2018:1), Naidoo (2019:1-7), Ntombana and Bubulu (2017:1-10) and Vellem (2017:1). Because of our history in South Africa, we need to apply dialogical and listening skills regarding racism (see also Baloyi 2018:4). In this study, I conversed with and listened to Afrikaans-speaking adolescents from a practical theological perspective in order to co-create positive unique outcomes.

We can create new imaginative possibilities through narrative approach - possibilities that point beyond the obvious context, including diverse stories that inspire and help as they benefit from each other (I-Thou). It will take time and effort, but we need to commit to building respect, mutual understanding and trust. Thus, the aim of this study was to listen to the stories of racism of Christian Afrikaner urban adolescents to facilitate dialogue with the God, the world and with each other (see also Naidoo 2019:3).

In this study, I position myself within the overarching paradigm of postfoundational theology as described by Müller (2011):

[T] he postfoundationalist approach is sensitive for both the danger of relativity and subjectivity in a multiverse rationality and of the rigidity and false claims of the universal rationality. Therefore, it consists of an effort to move beyond both foundationalist and nonfoundationalist claims. For that reason, it is called post-foundationalism ... (p. 2)

I think it would be unrealistic to say that my theological positioning would not have any influence on my relationship with the context and vice versa. In the same sense, my own auto-ethnographic narrative on racism couldn't stand alone and be removed from this research, nor could my theological positioning be ignored. I have my own story on this theological positioning and in no sense could it be viewed apart or without influence on my relationship with the context. That being said, I think the methodology used in this study and my personal positioning in theology are sensitive and open to both my own positioning and the context being studied.

Hence, we as practical theologians could make a meaningful contribution by facilitating the variety of stories where different story cultures are met (Müller 2011):

$[F]$ or the practical theologian one of these storying cultures would always be people's experiences of the presence of God in their lives. A focus on all these stories, including the religious story, does not make our contribution better than that of others, but it is unique. The so-called safe public space created by a wide reflective equilibrium becomes even more fragile because of the inclusion of the stories of the experience of God's presence. (p. 5)

This is a journey where the co-researcher's contextuality was upfront contributing in listening to in-context experiences and interpreting it together. 
The co-researchers in this research led me towards a primary focus on the work of Martin Buber and specifically on his concepts of I-It and I-Thou as a way of making sense of research contribution (in narrative language) towards a unique outcome of this problem. Not meeting one another as whole persons and instead collide as fragments is a great concern that came out during conversations.

The research clearly showed that by objectifying relationships (I-It), diverse engagement becomes almost impossible. Consequently, this article advocates for a subjective (I-Thou) approach towards building relationships in a context where people feel vulnerable and shameful, have fears, but also gain trust to contribute to meaningful dialogue with 'others'. This view is not forced, controlled or managed; it is simply the I-Thou walking into our lives (Buber 1965):

' $[B]$ etween' is not an auxiliary construction, but the real place and bearer of what happens between men; it has received no specific attention because in distinction from the individual soul and its context, it does not exhibit a smooth continuity, but is ever again re-constituted in accordance with men's meetings with one another. (p. 203)

According to Hycner (1995), the primary attitudes that a human being can take towards others are that of the I-Thou or I-It attitude (see also Lamola 2018:3). The former is a natural attitude of 'connection' and the latter is a natural attitude of 'separation'. The I-Thou attitude is an experience of appreciating the 'otherness', uniqueness, and the other person reciprocates the wholeness of another. The I-It attitude is not wrong, or evil, as it actually helps in achieving goals that one sets in life. However, when it is overwhelmingly predominant, it gets problematic and even tragic. When this objectifying attitude is out of balance with a dialogical approach to one's existence, as well as to others, it is rather problematic and tragic, as was so clear, for instance, from the ideology of apartheid.

\section{Findings}

\section{Listening to post-apartheid voices: 'IT'}

The co-researchers expressed rather explicit objectifying attitudes (I-It) during our conversations:

D1-17-M: 'On our farm the blacks just take everything they want, they steal wire cables and even though we take such good care of them. My father is currently in a court case after he shot and killed a farm worker for stealing his shoes and got in a scuffle with my dad when he reprimanded him. There is no respect for us [white people] on our farm'.

(Long silence)

D5-17-F: 'Our family also has a farm and we did everything for the farm workers. We gave them maize meal, housing and everything, but it was never enough. They always wanted more and that is frustrating'.

D1-17-M: 'Obviously, certain white people did harm to blacks in the past, but can't we just move on with our lives. Most white people are good to them [black people]'.
D1-17-M: 'They [black people] must stay separate like in the old days. You still get good ones [black people] that still call you boss [baas] and you can work with them, but you don't stay with them. They have their own way of doing things and therefore I prefer to stay separate'.

(Silence)

D1-17-M: 'Apartheid was meant well and tried to uplift the country'.

D6-16-F: 'Most of them are just so stupid and then they still get the work or the university exemption and that is unfair'.

D1-17-M: 'We [white people] work harder and therefore are prone to more success in life, it is how we were raised. One cannot trust them [black people], they just steal'.

(Silence)

D1-17-M: 'The culture of white people is that of more civilised because we [white people] were brought up better and with better values'.

Maluleke (2016) has underlined exactly this point in his interview at the Gordon Institute of Business Science (GIBS) that we focus on the physical attributes rather than the potential that lies in people. The I-It attitude constitutes an objectifying way of relating to a person - addressing and treating a person as we would address and treat any object in life. The I-It relationship is the way we typically treat each other for practical necessity, manipulation and means-ends instrumentality. This is called 'using' and 'experiencing' by Buber (1958:5-13; see also Horwitz 1978), that is, in terms of either an externalised 'out there' way of addressing each other or an internalised 'in here' one. According to Buber (1958:3-34), we speak the I-It with only part of our being (think of talking to someone and thinking of something else, such as lunch, whilst this dialogue is taking place). It is only a partially engaged way of addressing another person. Furthermore, the primary temporal modality of the I-It is the past. In other words, it is a way of treating each other governed mostly by things we know about the other person from past experiences and our own experiences of interaction or what we believe (traditions of interpretation) we know about the other person or group.

One way to recognise I-It in our lives would be to think about how frequently we try to objectify each other in our everyday interactions. It basically boils down to getting the other person to do what we want them to do and manipulate their behaviour accordingly to what we know or believe from that person's past experience in much the same way as we manipulate objects such as hammering a nail into a piece of wood. Most of the time it is quite difficult to acknowledge other people's deep humanity if you are entrenched with I-It thinking. The unpleasant truth is that most of the time with this thinking we only use each other to have what we really want. Boesak (2019) describes the process of caution in this instance incredibly well:

$[I] \mathrm{t}$ is for that reason that in the final analysis black South Africans, in our choice for reconciliation and reconciled diversity, chose political justice rather than victim's justice; distributive justice rather than retributive justice; justice for the living rather than revenge for the dead; a reconciled future rather than an 
unforgiven past; a shared hopefulness rather than a negotiated despair. (p. 7)

During conversations with co-researchers, they explicitly accused black people of oppressing them rather than the other way around. They did this because the object (black people) stood in their way of achieving goals and not one of togetherness. With this I do not state at all that black people cannot oppress other races, but we were specifically focusing on Afrikaner adolescents in this study:

A4-17-M: 'I think blacks and whites look down on one another both ways. I mean, look at all the discrimination against whites these days. Blacks are using every means that they can get to advance themselves even if they don't deserve it. I cannot study what I am entitled to study because of excellent grades in school because my skin colour is white. They [black people] want university education in their own language, but my brother told me there does not exist good engineering terms in their language and therefore Afrikaans is still more advanced and therefore it is not racism but pure logic. So I really don't understand what the big deal is'.

A2-18-M: 'I won't be able to get work one day because the blacks are pushed in front of us [white people] the whole time'.

A5-17-M: 'I agree, they [black people] are just looking for any excuse to blame whites for their problems. They oppress us [white adolescents] that was not even a part of apartheid and now they use apartheid to blame us. They just want to blame us and back it up with apartheid'.

During conversation with group B, it led to discussing the attitudes of black people, and again it was evident that black people were expected to do all bad things in life and that they were, in a sense, viewed as objects of $\sin$ (Fanon 1963):

$[T]$ he native is always on the alert, for since he can only make out with difficulty the many symbols of the colonial world, he is never sure whether or not he has crossed the frontier. Confronted with a world ruled by the settler, the native is always presumed guilty. (p. 52)

In group B's conversation, it was said that:

B5-16-F: 'What strikes me from what B6 just said is that, yes, it is not in their [black people] culture to break into our homes. I think it is more a case of our country that has certain stories in it that we are against one another, we are enemies. I mean, I would emphasise it when a black person is driving badly in front of us or we would emphasise it when a black person is helping a white person'.

B4-18-M: 'Because we [white people] work for everything and we always have. They [black people] just use us [white people]. They cannot stay in big houses and drive big cars in any other way than using us [white people] for it. They should work for all they want in the same way as I have to and we will see then whom [sic] comes out on top'.

It was also evident that the co-researchers looked upon other races, and especially black people, differently. If, for instance, an incident took place where a white adolescent would not be benefitted or even be in worst condition than previously, it was evident from this conversation in group $\mathrm{B}$ that the adolescents would react differently in the same situation because of benefactor's race:
B2-16-F: 'If a white person were to benefit from a situation where I myself would not, then I would refer to it as being unfair. If it is a black person benefiting from me that would be discrimination as they do not deserve it'.

B4-18-M: 'I agree, I have much more sympathy with people from my own ethnicity'.

B6-19-F: 'Like I mentioned before, my mother begged me to not marry a black person as it would be a downgrade for me in life'.

Obviously, the adolescents didn't have the terminology for this conversation and they were not familiar with Buber's philosophy, but it was clear that black people were viewed, in some instances, as objects and white people more as subjects. The I-It attitude seemed to become apparent when ethnicity was involved. This almost came naturally in the way these adolescents and I myself viewed the world and the relations we had within it.

In the conversation with group $\mathrm{C}$, a discussion emerged about the system in which the world operates and the coresearchers in this group felt that it was the system itself that had created unfairness towards other groups. Almost all of them said that they had no idea about race or differences in society until they went to primary school (a system):

C2-17-M: 'There will always be hate towards others as long as the system is unfair and treats people unfairly'.

Researcher: 'Do you think this hate you are talking about is vice versa between black people and white people?'

C2-17-M: 'I think so, because it seems that they [black people] really hate us and don't care whether we [white people] are allowed into university or sports teams and they would use the system of majority black rule to get what they need at the cost of whites. Perhaps we as whites did the same, but I just want the system to be equal'.

C3-17-F: 'Yes, I treat the workers [black people] in our home so nicely, and [sic] sometimes it seems that they don't really appreciate it, and they just use the system to force us [white people] being nice to them, otherwise we will go to a court of law'.

The I-It attitude was evident here. One thing noticed here was that the co-researchers saw themselves as victims at this stage of the conversation. They realised at this point that black people were victims at one stage in history, but all things had been fixed now and that things would be perfectly fair. It seems that the co-researchers in this group had no acknowledgment of the real effect of the past that still affected the lives of most black South Africans even until this day. They agreed that some things were not fine in the past, but that they were solved after the end of apartheid. The privileges bestowed upon them as a result of apartheid seemed to have no effect on their reasoning at this stage. They only wanted things or objects in the lives of all South Africans to be fair because they knew they could outplay and outperform most black people as a result of their education and training. Ironically, this was because of the privileges they had obtained through a system called apartheid. This notion of not fully acknowledging the effect of a privileged past over others was something the co-researchers struggled with. Unknowingly, the co-researchers benefitted 
under colonialism, their whiteness and the apartheid regime and a history of more advanced training, schooling and monetary ability (Giliomee 2003).

It was the perfect example of the I-It attitude taking control over the fascinating and diverse world in which we live in South Africa.

Group D had more or less the same conversations on this topic as we had in group C:

D6-16-F: 'I really do not know what the big deal is. I mean most of them [black people] were not even born in the apartheid era. Can we just get on with South Africa, please?'

D5-17-F: 'I agree; we were not even born in the apartheid era, why should we take so much discrimination against us [white people]'.

It was clear at this stage of the conversation that the I-It attitude, as explained by Buber (1958:3-34), was present in Afrikaner urban adolescents in the way they looked at the world they were living in today. Although our social and cultural lives could lead us evermore away from the 'Thou' and into the domain of 'It', Buber (1958:37-72) speculated on the possibility of what he called 'the return'. This is the possibility of returning to the I-Thou attitude as our primary way of addressing each other in today's world. What is required for 'the return' to the I-Thou attitude is, as Buber (1958) has stated on many occasions, 'to call the incubus of the world of I-It by its true name; in other words, to call it exactly what it is (see also Rohr 2016): An imbalance in our relation with life that short-circuits our chance to experience real relation, real transcendence and real spirituality.' According to Buber (1958:37-72), the main impediment affecting this return is a kind of capriciousness that runs through our time. Buber (1958:37-72) has put it numerous times that a capricious person does not believe in encounter, he does not know association, he only knows the feverish world out there and his desire to use it. Perhaps the best thing for us to do is to allow ourselves to be more sensitive to potential I-Thou moments and to cultivate the courage to enter into those moments when they take place.

\section{Listening to post-apartheid voices: 'THOU'}

In contrast to 'Thou', the I-Thou attitude has to do with what Buber (1958:3-35) calls relation or encounter. This has to do with being completely present for another person rather than only partially engaged. It also has to do with addressing each other with a sense of mutuality and reciprocity by recognising and affirming the other person's full humanity with our full humanity. In this, the primary temporal modality is the spontaneous unfolding of the present rather than the past. The I-Thou attitude happens in the 'here and now', as opposed to the 'there and then'. According to Buber (1958:62-63), the I-Thou attitudes are important in our lives for many reasons. Experiencing the I-Thou moments is one of the most precious parts of human birth. Furthermore, the I-Thou is the locus of all genuine creative activity, all genuine spirituality and all becoming in transcendence. It basically comes down to Buber from the notion that there is no such thing as growing as a human being all on our own, at least not in any deep way. All moments of genuine growing and becoming require an I-Thou; in other words, they unfold between people, rather than within or outside people. Moments of transcendence basically occur in the unpredictable flexion of a genuinely fully engaged relationship with each other.

Buber (1958) constantly points out that the I-Thou moments do not rise out of wilful activity alone. The opportunity to experience I-Thou arises from grace, but then we also have to choose to enter into the I-Thou experience wilfully by choice. In other words, the I-Thou attitude requires both will and grace. Although it comes to us, we must also choose to enter into it. As Buber (1958) has so often asserted, the relation is election and electing, passive and active at once.

During conversations with co-researchers of group A, some of the participants were ranting about how much better white people were and that they had better education and had come from a better ancestry. This was a real I-It dialogue. One of the co-researchers then mentioned something as follows:

'I hear what you say, but is that really so important? I mean when we go to Mozambique on holiday, for instance, I cannot help but to notice the pure joy and laughter I witness from children there. Yes, they don't have what I have, but I don't have what they have. This makes me wonder about our world we live in and if it really is that superior'. (Participant A4, age 17, male)

These remarks made by A4-17-M changed the direction of our conversation almost as if the I-Thou had now come to them. Group A co-researchers started (chose to wilfully enter I-Thou) to see others as I-Thou and not I-It, or at least started to question attitudes. I decided not to interfere with questions at this stage and allowed the conversation to lead us:

A8-17-M: 'What you just said made me think that blacks are not that bad actually. I cannot begin to describe the caring and sharing most of them have in my school. One day I did not have any food at school and a black student saw this and offered to buy me a sandwich from the tuck shop. That was pretty cool. The other thing that I notice from black children in my school is the respect they treat their parents with. I mean us whites are so cheeky and demanding towards our parents most of the time and I think they set a great example to follow'.

A4-17-M: 'I agree with you A8. I would actually like to ride in a minibus taxi sometime. My mom will have a heart attack, but I want to do it sometime. This conversation is making me rather curious about black people and maybe we can even learn from them. The thing is that we get so bombarded at home and through white society that blacks are bad, but what if... it is not so, what if... we dare to know them, what if... we can get along?'

I sensed that things had started to move ahead among the co-researchers and I did not want to interfere too much so I simply asked, 'after hearing these stories of black people that we just heard, I am curious what the rest of you think about this?' 
Then A3-16-F started talking. A3-16-F was the person who stated that white people were cleaner, that they had a better culture, that they managed better, and that these things were just like second nature to white people:

'I do hip-hop dancing as you all know. This is terrible, but I must admit blacks are so much friendlier than whites. I learn a lot from blacks in dancing, they have so much more rhythm than us whites and they never hesitate to help me. I think I label some black people unfairly and I assume stereotypes, I don't feel too good now about what I said before'. (Participant A3, age 16, female)

I could sense that A3-16-F was not in a good space at this stage being confronted with her own attitude. I asked some externalising questions to give A3-16-F a sense of the real problem and that she was not the problem. This helped her to grasp the problem, rather than feeling embarrassed. A5-17-M was still sticking to his guns at this point, saying 'that black people are lazy and he won't talk to a black person unless they were like him'.

I think some comments made in group B were relevant to this topic. We were discussing their parents and the effect that their parents' thinking and upbringing had on them and on the way they talk in front of their parents and then talk differently to the outside world:

B6-19-F: 'There is no doubt that we whites are just being politically correct. We talk differently to the outside world and I don't think that is a good thing. Are we being hypocrites, liars or what are we doing here? We cannot go on like this; we need to have a hard look towards our attitude. The worst of all is that we are so-called Christians'.

B2-16-F: 'I think God's heart is breaking when he sees how we work with other people. It's like backstabbing God. It's like we love others, but with conditions'.

B5-17-F: 'Ok, I hear what you are saying. We are actually all lost, it is like we love others but with certain criteria that fits us. I think this is how we approach God sometimes, almost like ticking off criteria on the Jesus list and I don't think God is like that at all'

B1-17-M: 'What would Jesus say about all the things we said?'

B6-19-F: "That is a good question. Obviously, he is a God of love and forgiveness and I know he has so much grace over all of us, but I think we are missing something here. Maybe, I need to look at my relationship with God afresh and why I am a Christian'.

B5-16-F: 'Yes, we are different as humans but why can't we be one in humanity? This is heavy stuff, but it makes sense. B6, I think we all need to look at our relationship with God afresh'.

\section{Assumption that unmasked 'IT' had opened the door for 'THOU'}

In the conversation with group $\mathrm{D}$, something happened by mistake from my side but it revealed something else. This was the last group I had a conversation with, and they were talking about how black people were so much better in the old days and they were happy with minimal and not like today's black people who just demand. All other groups - A, $\mathrm{B}$ and $\mathrm{C}-$ invited Jesus in their conversation spontaneously, but for some reason my guard slipped and in group D I said, 'we will get back to that topic again later on when I am going to invite someone into this conversation'. I assumed they wanted to talk about Jesus like the other three groups. I meant inviting Jesus, but all co-researchers thought I was going to invite a black person. At this stage, many bad things were said about black people, and they thought I was going to expose them in front of a black person. There was a physical reaction in all of them, moving chairs and sitting up straight with big eyes. I immediately realised my mistake and corrected it and apologised to the group for assuming a topic, but I was now curious about the reaction that took place in the room. I then asked, 'I am curious as to what this reaction that just happened is saying to us?'

D4-17-M: 'I really thought you were going to bring in a black person and I was thinking about all the things we already said up until this point. I got a big scare and I just realised something... [pause for a few seconds] ... I am a racist. I talk behind the backs of people and play the game in front of them. I am scared now by realising how much I look down on black people. I thought I was okay, because in public I am okay and do not harm anybody, but in my core I am corrupt and racist'.

D3-16-F: 'I agree; I now realise this more than I have ever realised it'.

D1-17-M: 'I agree; I am actually shocked thinking back on what we said'.

D3-16-F: 'I feel guilty; I have the guts to say things behind the backs of people but not in front of them'.

D6-16-F: 'This is as un-Christian as can be'.

D5-17-F: 'Maybe inviting Jesus into this conversation is not such a bad idea after all. Maybe we are looking just too shallow on our own and need Jesus to help us look deeper into this'.

D6-16-F: 'Jesus sees more than just a human being'.

D4-17-M: 'Jesus doesn't see skin colour. I am now thinking of that poem that Bouwer Bosch wrote - Kleurblind [colour-blind]. Can I Google it and read it to the group?'

Researcher: 'You are more than welcome to do so'.

(Silence)

D4-17-M: 'Here it is...' [Afrikaans poem]

(Reading it to the group)

... (Silence)

D4-17-M: 'So Jesus didn't die on a cross for the colour of your skin. I can't sit here and claim that I am a Christian and a racist. It simply does not resonate'.

D5-17-F: 'I know you [Researcher] apologised for that [introducing Jesus], but actually we need to thank you, when D4 was reading I just realised the truth of all that he said. I think I am racist and I want to do something about this. Yes, we can blame ourselves or we can tackle this issue and create a better world for all'.

D1-17-M: 'That just blew me away, I don't know what to say now'.

Researcher: 'What is the first thing that jumps to your mind?'

D1-17-M: 'That I am sorry, that I need to stand in the shoes of a black man before I do anything'.

D4-17-M: 'This helps me; I got some distance from myself. Looking at it from another perspective - God's perspective, perhaps. We are actually so well equipped as Christians to deal with these things. Why are we not dealing with this? 
Jesus guides us and we don't even see it. We just look at ourselves and miss him completely. We just went on and on in this conversation'

D3-16-F: 'This conversation made me realise serious things in my own life that need work. However, I don't actually feel that guilty because forgiveness is what God is all about. I just have this urge now to live out that which I claim to believe - God's love. It is almost as if Jesus touched me now. I actually want to embrace God's love with all people. That's what Jesus did. It's going to be hard though, but possible'.

D5-17-F: 'I feel so much more aware now'.

D2-17-F: 'I am not a racist, but they do still make me angry. I think a little different now'.

D6-16-F: 'Some of us whites are actually very stupid, I can't believe I said that of blacks. I want to make a difference but I don't know how. I will sit with Jesus like D4 said and I believe he would guide me in this'.

D4-17-M: 'I agree; one needs to address this'.

D2-17-F; D1-17-M; D3-17-F; D6-16-F: 'Yes'.

\section{Discussion}

\section{Deconstructing 'IT'}

The assumption I made during the conversation with group $\mathrm{D}$ fortunately turned out to be something real and made all of us realise how objectively, rather than subjectively, we could look at people. In group D and through an honest mistake, the moment of I-Thou walked in. Similarly to other groups, the co-researchers willingly chose to walk into the I-Thou moment, which meant we were on our way to 'the return' being an I-Thou.

Buber's (1958) I and Thou present a philosophy of personal dialogue, in that it describes how personal dialogue could define the nature of reality (see also, Friedman 2002). Buber's major theme is that human existence may be defined by the way in which we engage in dialogue with each other, with the world, and with the God. According to his theory, I-Thou is a relation of subject-to-subject, of mutuality and reciprocity, whilst I-It is a relation of subject-to-object, of separateness and detachment. If one is to analyse a subject, it is no longer a subject but rather an object. This implies that there is no fluidity between subjects anymore; for example: Mistrust takes it for granted that the other dissembles so that, rather than genuine meeting, conversation becomes a game of unmasking and uncovering unconscious motives. Buber criticises Marx, Nietzsche and Freud for meeting the other with suspicion and perceiving the truth of the other as mere ideology. In the same sense, as Buber accepted the 1953 Peace Prize of the German Book Trade, 'Genuine Dialogue and the Possibilities of Peace', Buber (1957:234-239) argues that the precondition for peace is dialogue, which in turn rests on trust. In mistrust, one presupposes that the other is likewise filled with mistrust, leading to a dangerous reserve and lack of candour. We need to understand human existence as a dialogue of fluidity with each other, the world, and with the God.
If we are to understand and analyse the Trinity as three separate entities, for example, we would completely miss the unity and fluidity and dialogue of this subject-to-subject-tosubject. Many people would refer to God as love. Love, as a relation between $I$ and Thou, is a subject-to-subject relation. In this relation each other's unity of being is perceived. Love is an I-Thou relation in which subjects share this unity of being. Love is also a relation in which $I$ and Thou share a sense of caring, respect, commitment and responsibility. The I-Thou relation is an ideal relation; the I-It relation is an inescapable relation by which the world is viewed as consisting of knowable objects or things like racism. The I-It relation is the means by which the world is analysed, controlled and described. However, the I-It relation may become an I-Thou relation, and in the I-Thou relation we can interact with the world in its whole being. Thus, if we engage God as an I-Thou, we can interact with God in his whole being, Father, Son, Holy Spirit and even more. It is possible that we as a diverse people can thus interact within the whole being of each other. The I-Thou relation may have either potential being or actual being. When the I-It relation becomes an I-Thou relation, the potential being of I-Thou relation becomes the actual being of the I-Thou relation.

\section{Attitude and moment}

We saw some movement from I-It to I-Thou during conversations with co-researchers in above sections. The ship was clearly sinking in an ocean of racism backed by traditions of interpretation inherited within the Afrikaner culture. It seemed, however, that before all was lost the awareness of life rafts saved the day and gave us hope for a new life. The fact that we are on life rafts through awareness raises the following question: Whether this is just a 'moment' in the I-Thou that would soon fall back in to what seems to be the default mode of I-It, or is it truly the beginning of an I-Thou 'attitude'?

It is important to differentiate the I-Thou 'attitude', or the dialogical, from the I-Thou 'moment'. The dialogical is not the same as the moment, as the word 'moment' suggests only something briefly that came and went by. According to (Hycner 1995:10): 'An I-Thou encounter is but one moment, or dimension, of an overall rhythmic dialogical approach encompassing the alternation of I-Thou and I-Thou moments'. This moment, although exceptional in its living experience, could have the effect of an over emphasised or inflated I-Thou experience. It is especially true if a person makes it a goal to achieve this I-Thou, something that we saw happening after the moment of awareness, the co-researchers wanted to make it a goal to achieve and fix the problem. The irony is that it becomes an I-It encounter. Buber (1958) was very clear on this, as already mentioned, that one cannot just decide to have an I-Thou encounter, one needs to prepare the ground for when it might occur. The reality is that we can only be as present as we are in an encounter and we cannot enforce this on ourselves nor on any other person to engage in genuine dialogue. This unfortunately is completely outside our control: 'The Thou meet me through grace, it is not found in seeking' (Buber 1958:11). Genuine dialogue is mutual. It can't 
be forced. It can't be held onto. We need to be open to its ebb and flow (Buber 1958):

$[T]$ hrough the graciousness of its comings and the solemn sadness of its goings it leads you away to the Thou in which the parallel lines of relations meet. It does not help to sustain you in life, it only helps you to glimpse eternity. (p. 33)

The reality of this is that we need to be open to, and want this experience to occur, yet not trying to force it (Hycner 1995:10). One needs to get into the life raft, ready to encounter the ocean and wanting to survive, but a life raft can't be controlled like a ship with a rudder. Perhaps the ocean can take us along, not forcing our way. This could be an option for us to abandon our ships called racism, and perhaps 'grace' can meet us there in the ocean streams.

\section{Conclusion}

Racism is alive and well in South Africa and does not exclude the so-called 'freeborn'; yes, it needs deconstruction, and this research wants to put a way (not the way) forward in advancing one step closer in achieving this. Deconstructing racism lies in the efforts of individuals and systems to become bridges to truly connect with 'others' (I-Thou). This should encourage us to physically and mentally leave our comfort zones and find life in the uncertain terrain of otherness where diverse people contribute to each other's humanity (I-Thou). On this journey we need awareness and the courage to change some of our de facto beliefs and attitudes.

This research indicates that if we sacrifice our 'little will', which is unfree and ruled by things, and drives to our 'great will', we move away from being determined to find destiny. In essence, this research shows that our greatest enemy in this life is small-selves (false-self) that we usually think we are. Through Buber's philosophy, this research amounts to an incisive critique of the systemic imbalances and pathologies that run through many of our Afrikaner adolescents, but it also offers the paradigm of a powerful and compelling alternative to us. Perhaps in the final analysis the central question is whether in our way of life where so much draws us further and further into the world of ' $\mathrm{It}^{\prime}$ we can nonetheless find within ourselves the sensitivity to detect the opportunity to enter into a real relationship with each other and then have the courage to actively do so - a question that plays out across our lives both individually and socially.

\section{Acknowledgements Competing interests}

The author declares that he has no financial or personal relationships that may have inappropriately influenced him in writing this article.

\section{Author's contributions}

S.v.D. is the sole contributor of this article, which was derived from his doctoral thesis under the supervision of
Prof. J. C. Müller (Department of Practical Theology, Faculty of Theology, University of Pretoria).

\section{Ethical considerations}

The author obtained research ethics approval for the research of his doctoral thesis as described and quoted in this work. The author declares that he observed the ethical standards required in terms of the University of Pretoria's code of ethics for researchers and the policy guidelines for responsible research.

\section{Funding information}

This research received no specific grant from any funding agency in the public, commercial or not-for-profit sectors.

\section{Data availability statement}

Data sharing is not applicable to this article as no new data were created or analysed in this study.

\section{Disclaimer}

The views and opinions expressed in this article are those of the author and do not necessarily reflect the official policy or position of any affiliated agency of the author.

\section{References}

Baloyi, E.M., 2018, 'A continued racial character of some of the Gereformeerde Kerke in South Africa: Strategic moves evading reconciliation and unity of churches in post-apartheid South Africa', HTS Teologiese Studies/Theological Studies 74(1), 4782. https://doi.org/10.4102/hts.v74i1.4782

Besley, A.C., 2002, 'Foucault and the return to narrative therapy', British Journal of Guidance and Counseling 30(2), 125-143. https://doi.org/10.1080/03069880220128010

Blum, L., 2002, 'I'm not a racist but...' The moral quandary of race, Cornell University Press, Ithaca, NY.

Boesak, A.A., 2019, 'Testing the inescapable network of mutuality: Albert Luthuli, Martin Luther King Jr. and the challenges of post-liberation South Africa', HTS Teologiese Studies/Theological Studies 75(4), a5297. https://doi.org/10.4102/hts. v75i4.5297

Buber, M., 1957, Pointing the way: Collected essays, transl. M. Buber from the German and M. Friedman (ed.), Harper \& Brothers, New York, NY.

Buber, M., 1958, I and Thou, transl. R.G. Smith, Charles Scribner's, New York, NY.

Buber, M., 1965, Between man and man, transl. R.G. Smith, The Macmillan, New York, NY.

Fanon, F., 1963, The wretched of the earth, Grove Press, New York, NY.

Freedman, J. \& Combs, G., 1996, Narrative therapy: The social construction of preferred realities, W.W. Norton, New York, NY.

Friedman, M.S., 2002, Martin Buber: The life of dialogue, Routledge, New York, NY.

Giliomee, H., 2003, The Afrikaners: Biography of a people, C. Hurst, London.

Giliomee, H. \& Mbenga, B., 2007, Nuwe Geskiedenis van Suid-Afrika, Tafelberg, Cape Town.

Heitink, G., 1999, Practical theology: History, theory, action domains - Manual for practical theology, transl. R. Bruinsma, William B. Eerdmans, Grand Rapids, MI.

Horwitz, R., 1978, Buber's way to I and thou. An historical analysis, Schneider, RueilMalmaison.

Hycner, R., 1995, 'The dialogic ground', in R. Hychner \& L. Jacobs (eds.), The healing relationship in gestalt therapy, pp. 3-30, The Gestalt Journal Press, New York, NY.

Lamola, M.J., 2018, 'Blackhood as a category in contemporary discourses on black studies: An existentialist philosophical defence', Transformation in Higher Education 3(1), a55. https://doi.org/10.4102/the.v3i0.55

Maluleke, T., 2016, Deconstructing racism, viewed 03 December 2019, from https:// www.youtube.com/watch?v=4zATJzV-oLg.

Mashau, T.D., 2018, 'Unshackling the chains of coloniality: Reimagining decoloniality, Africanisation and reformation for a non-racial South Africa', HTS Teologiese Studies/Theological Studies 74(3), 4920. https://doi.org/10.4102/hts.v74i3.4920

Meylahn, J.A., 2014, 'Postfoundational practical theology as public Christology', Verbum et Ecclesia 35(2), 1-11. 
Meylahn, J.A., 2015, 'After God: Practical theology as public Christology from the margins of the market', HTS Teologiese Studies/Theological Studies 71(3), 1-9. https://doi.org/10.4102/hts.v71i3.2975

Monk, G., Winslade, J., Crocket, K. \& Epston, D., 1997, Narrative therapy in practice: The archeology of hope, Jossey-Bass, San Francisco, CA

Müller, J.C., 2006, Opleiding: Noodsaaklikevertrekpunte met die oog op die teologieseopleiding in die NG Kerk. 22 paragrawe, viewed 21 January 2011, from http://www.teo.co.za/wmprint.php?ArtID=3.

Müller, J.C., 2009a, 'Postfoundationalism as a practical way of interdisciplinary dialogue: Narrative research on HIV and AIDS', International Journal of Interdisciplinary Social Sciences 3(9), 77-86.

Müller, J.C., 2009b, 'Transversal rationality as a practical way of doing interdisciplinary work, with HIV and AIDS as a case study', Practical Theology in South Africa 24(2), 199-228.

Müller, J.C., 2011, 'Postfoundational practical theology for a time of transition', HTS Teologiese Studies/Theological Studies 67(1), 837. https://doi.org/10.4102/hts. v67i1.837
Müller, J.C., 2013, 'Practical theology as part of the landscape of social sciences and humanities: A transversal perspective', HTS Theological Studies 69(2), 1-5. https://doi.org/10.4102/hts.v69i2.1299

Naidoo, M., 2019, 'So, what's your story? - The role of storytelling in nurturing inclusive congregational identity', HTS Teologiese Studies/Theological Studies 75(4), a5448. https://doi.org/10.4102/hts.v75i4.5448

Ntombana, L. \& Bubulu, T., 2017, 'Shifting boundaries of racial space in postapartheid South Africa: The case of Afrikaner youth in East London', The Journal for Transdisciplinary Research in Southern Africa 13(1), a432. https://doi.org/ 10.4102/td.v13i1.432

Rohr, R., 2016 'Richard Rohr on white privilege', Huffington Post, viewed 10 March 2016, from www.huffingtonpost.com/romal-tune/richard-rohr-on-white-pri_b_8985742. html?.

Vellem, V.S., 2017, 'Un-thinking the West: The spirit of doing black theology of liberation in decolonial times', HTS Teologiese Studies/Theological Studies 73(3), a4737. https://doi.org/10.4102/hts.v73i3.4737

Yang, P.Q., 2000, Ethnic studies: Issues and approaches, State University of New York Press, New York, NY. 